\section{Mutations in the hepatocyte nuclear factor- $1 \beta$ (MODY5) gene are not a major factor contributing to end-stage renal disease in Japanese people with diabetes mellitus}

\begin{abstract}
Dear Sir,
Mutations in the homeodomain-containing transcription factor hepatocyte nuclear factor (HNF)- $1 \beta$ are the cause of one form of maturity-onset diabetes of the young (MODY5) [1]. This form of diabetes is characterized not only by early-onset autosomal dominant diabetes mellitus and beta-cell dysfunction but also by renal dysfunction which is progressive and leads to early-onset end stage renal disease (ESRD) in many carriers [2-4]. The mutations that have been identified in HNF- $1 \beta$ have diverse effects on the activity of this transcription factor $[1,3,5,6]$ with some resulting in loss-of-function (R177X and R137-K161del) whereas others in gain-of-function (P328L329fsdelCCTCT) or affect HNF-1 $\beta$ activity by a dominant-negative mechanism (A263fsinsGG). The different effects of mutations on the functional properties of HNF-1 $\beta$ possibly account for the variation in renal phenotype found in patients with these mutations. Weng et al. recently screened the HNF- $1 \beta$ gene for mutations in 130 patients of Scandinavian ancestry including 115 with early-onset diabetes and 15 with diabetic nephropathy [7]. They found two new missense mutations. The mutation G492S was found in the hetrozygous state in 4 of $115(3.5 \%)$ diabetic probands and 3 of $92(3.3 \%)$ non-diabetic control subjects. The mutation A241T was found in the heterozygous state in 1 of $15(6.7 \%)$ subjects with dia-
\end{abstract}

N. Iwasaki, T.Babazono, O. Tomonaga, M. Ogata, H. Yokokawa, Y. Iwamoto, Diabetes Center, Tokoyo Women's Medical University

Acknowledgements. This work was supported by grants from the Ministry of Health and Welfare (for research on the human genome and gene therapy), the Ministry of Science, Culture and Sports (10671084, 12204102, 70203370), the Naito Foundation, the Uehara Memorial Foundation, and the Japan Diabetes Society Foundation. betic nephropathy and 0 of 92 control subjects. Although the relation between these two missense mutations and diabetes or renal dysfunction, or both, still needs to be established, the results of Weng et al. suggested that HNF-1 $\beta$ mutations might be a relatively important genetic factor contributing to the development of renal disease.

The aim of this study was to determine the prevalence of mutations in the HNF- $1 \beta$ gene amongst Japanese patients with early-onset diabetes and progressive kidney disease. The study group comprised 54 unrelated diabetic patients $(\mathrm{M}: \mathrm{F}=34: 20)$ with ESRD. All patients were attending the Diabetes Center of Tokyo Women's Medical University and had started hemodialysis or peritoneal dialysis treatment before the age of 50. Informed consent was obtained from all subjects before the study. The age of subjects at the time of the study was $44.8 \pm 6.9$ years (means \pm SD) and type of diabetes mellitus was MODY $(n=4)$, Type I (insulin-dependent) diabetes mellitus $(n=7)$, Type II (non-insulin-dependent) diabetes mellitus $(n=43)$. The mean age at diagnosis of the disease was $24.4 \pm 9.1$ years as a whole, and MODY, Type I and Type II diabetes $(16.0 \pm 6.4$ years / $12.9 \pm 7.7$ years / $27.4 \pm 7.3$ years, respectively). The duration of diabetes was $21.1 \pm 9.7$ years, and the age at the start of hemodialysis or peritoneal dialysis was $40.7 \pm 6.4$ years. The family history of diabetes was MODY $(n=4)$, Type I $(n=4)$, Type II $(n=32)$. The minimal promoter, protein coding region and splice-donor and acceptor sites of the $H N F-1 \beta$ gene were screened for mutations by amplifying the nine exons and minimal promoter region using specific primers as described [1]. PCR was carried out in a $100 \mu \mathrm{l}$ volume containing $25 \mathrm{~mol} / \mathrm{L}$ Tris-HCI, $\mathrm{pH} 8.0$, $50 \mathrm{mmol} / \mathrm{L} \mathrm{KCl}, 1.5 \mathrm{mmol} / \mathrm{L} \mathrm{MgCI}_{2}, 5 \mathrm{mmol} / \mathrm{L}$ dNTPs, 30 pmol of each primer, $0.4 \mu \mathrm{l}$ of EX Taq (Takara, Kyoto, Japan), and $1 \mu \mathrm{l}$ of genomic DNA. The cycling condition was the touch-down program using a Gene Amp PCR System (Perkin-Elmer Applied Biosystems, Foster City, Calif., USA), starting with $5 \mathrm{~min}$ at $94^{\circ} \mathrm{C}$ followed by total of 30 cycles of touch-down PCR for $1 \mathrm{~min}$ at $94^{\circ} \mathrm{C}, 1 \mathrm{~min}$ at $68^{\circ} \mathrm{C}$ to $62^{\circ} \mathrm{C}$ in the first 12 cycles, with a decrease of $0.5^{\circ} \mathrm{C}$ in each cycle, followed by 18 cycles at $62^{\circ} \mathrm{C}$, then $2 \mathrm{~min}$ at $72^{\circ} \mathrm{C}$, and final extension of $10 \mathrm{~min}$ at $72^{\circ} \mathrm{C}$. The PCR products were purified with Ultrafree-MC column (Millipore, USA), and the sense strands were sequenced using a Big Dye Terminator Cycle Sequencing kit with an ABI 377 DNA Sequencer (Perkin-Elmer) Sequences that were ambiguous were repeated and also determined on the antisense strand. 
Table 1. Polymorphisms in the human $H N F-1 \beta$ gene in Japanese subjects with diabetes mellitus and renal dysfunction

\begin{tabular}{lllll}
\hline Location & $\begin{array}{l}\text { Nucleotide } \\
\text { change }\end{array}$ & Genotype & Frequency Allele frequency \\
\hline Intron 8 & $\mathrm{nt}+48$ & $-/-$ & $40 / 54$ & Insertion C -0.13 \\
& insertion C & -/ins & $14 / 54$ & \\
& $\mathrm{nt}-22 \mathrm{C}>\mathrm{T}$ & $\mathrm{C} / \mathrm{C}$ & $32 / 54$ & $\mathrm{C}-0.70, \mathrm{~T}-0.30$ \\
& & $\mathrm{C} / \mathrm{T}$ & $12 / 54$ & \\
& & $\mathrm{~T} / \mathrm{T}$ & $10 / 54$ & \\
\hline
\end{tabular}

We found no mutation in this group of patients. We did, however, observe two polymorphisms in intron 8 (IVS8nt +48 ins $C$ and IVS8nt-22C/T) with frequencies of the major allele of 0.87 and 0.70 , respectively (Table 1 ). Both polymorphisms have been observed previously in Japanese subjects [1]. Contingency table analysis showed no significant difference in the frequencies of two intron 8 polymorphisms between the group of patients with diabetes, ESRD, or a group of 53 unrealted non-diabetic control subjects. The proband in the family with R177X mutation had started hemodialysis treatment at 23 years of age [1]. If we include this subject the prevalence of the mutation in the HNF- $1 \beta$ gene would therefore be less than $2 \%$.

Our study suggests that mutations in the $H N F-1 \beta$ gene are not a major factor contributing to the development of ESRD in Japanese diabetic subjects.

Yours faithfully, N. Iwasaki, T. Babazono, O. Tomonaga, M. Ogata, H. Yokokawa, Y.Iwamoto

Diabetes Centre, Tokyo Women's Medical University

\section{References}

1. Horikawa Y, Iwasaki N, Hara M et al. (1997) Mutation in hepatocyte nuclear factor- $1 \beta$ gene (TCF2) associated with maturity-onset diabetes of the young. Nat Genet 17: 384-385

2. Nishigori H, Yamada S, Kohama T et al. (1998) Frameshift mutation, A263fsinsGG, in the hepatocyte nuclear factor$1 \beta$ gene associated with diabetes and renal dysfunction. Diabetes 47: 1354-1355

3. Lindner TH, Njølstad PR, Horikawa Y et al. (1999) A novel syndrome of diabetes mellitus, renal dysfunction and genital malformation associated with a partial deletion of the pseudo-POU domain of hepatocyte nuclear factor- $1 \beta$. Hum Mol Genet 8: 2001-2008

4. Bingham C, Ellard S, Allen L et al. (2000) Abnormal nephron development associated with a frameshift mutation in the transcription factor hepatocyte nuclear factor-1 $\beta$. Kidney Int 57: 898-907

5. Tomura H, Nishigori H, Sho K, Yamagata K, Inoue I, Takeda J (1999) Loss-of-function and dominant-negative mechanisms associated with hepatocyte factor- $1 \beta$ mutations in familial Type II diabetes mellitus. J Biol Chem 274: 12975-12978

6. Wild W, von Strandmann EP, Nastos A et al. (2000) The mutated human gene encoding hepatocyte nuclear factor$1 \beta$ inhibits kidney formation in developing Xenopus embryos. Proc Natl Acad Sci USA 97: 4695-4700

7. Wenig JP, Lehto M, Forsblom C, Huang X, Li H, Groop LC (2000) Hepatocyte nuclear factor- $1 \beta$ (MODY5) gene mutations in Scandinavian families with early-onset diabetes or kidney disease or both. Diabetologia 43: 131-132 